\title{
Seven Decades of Publishing with the Institute of Geophysics, Polish Academy of Sciences
}

\author{
Anna DZIEMBOWSKA \\ Institute of Geophysics, Polish Academy of Sciences, Warsaw, Poland \\ $\triangle$ anna@igf.edu.pl
}

\begin{abstract}
Seven years have passed since the last brief outline of the editorial output of the Institute of Geophysics, Polish Academy of Sciences, was published (Dziembowska and Wernik 2014); the present text is a continuation and updating of this article, adding the developments over the last decade. The basic three publications have been successfully expanding, in terms of both in the number of issues, and, more importantly, in their scientific value and influenciality in the scientific world. These are: Acta Geophysica, GeoPlanet Book Series, and Publications of the Institute of Geophysics, Polish Academy of Sciences.
\end{abstract}

\section{INTRODUCTION, HISTORY}

The seventy-year editorial output of the Institute of Geophysics, Polish Academy of Sciences, is very rich, both in terms of thematic variety and the number of publications. The topics varied over the years, but have always been related to geophysical problems dealt with by the Institute's staff. The leading topics are: seismology and physics of the Earth's interior, study of deep structures of the Earth, magnetism and paleomagnetism, atmospheric optics, study of ozone and atmospheric electricity, physics and structure of the ionosphere, cosmic rays, planetary geodesy, polar research, oceanology, and hydrology.

The history of publishing mirrors the 70-year history of the Institute. The Institute of Geophysics ${ }^{1}$ was established in 1952 as one of the units of the newly created Polish Academy of Sciences. The Institute followed the long tradition of world-renown achievements of Polish geophysicists. The Chair of Mathematical Geophysics and Meteorology was established by Prof. Maurycy P. Rudzki at the Jagiellonian University in Cracow in 1985. It was the first academic chair bearing the name of Geophysics in Europe. The Teisseyre-Tornquist transcontinental tectonic zone, presently called the Trans-European Suture Zone, was recognized by Polish geologist Prof. Wawrzyniec Teisseyre in the late 1890s. More about the history of geophysics in Poland can be found, e.g., in: Ołpińska-Warzechowa (1995) and Kowalczuk (2001).

The Institute incorporated the hitherto operating geophysical observatories, in particular those in Warsaw, Świder, Racibórz, and Hel, and developed new ones, the main being the Central Geophysical Observatory at Belsk, and the Polish Polar Station Hornsund, Spitsbergen. Our

${ }^{1}$ Strictly speaking, until 1970 it was the Department of Geophysics (Zakład Geofizyki) 
publications document the vast amount of data collected. In some fields, the long series of bestquality observation results are unique on the world scale (e.g., ozone data) and provide an excellent source for studying the long-term tendencies.

Great influence on the early period of Institute's activity was exerted by the International Geophysical Year 1957/1958, which brought about a lot of research results and publications. They included vast documentation of expeditions to the Arctic, where the Polish Polar Station was established, to the Antarctic region, and to North Vietnam, where permanent geophysical stations were organized and long-lasting cooperation was initiated. In the next years, the resulting documents were edited and published jointly with the Vietnamese Committee for International Cooperation.

\section{EARLY PUBLICATIONS}

The early publications were mainly concerned with experimental results from the geophysical observatories, and were issued as separate bulletins/yearbooks of a given observatory. Since 1964 they have been gradually incorporated into the newly created series Materiaty $i$ Prace.

\subsection{Seismological bulletins}

Seismological bulletins issued as separate publications were the following: Biuletyn Obserwatorium Sejsmologicznego w Warszawie (Bulletin of the Seismological Observatory in Warsaw), Biuletyn Ślaskiej Stacji Geofizycznej w Raciborzu (Bulletin of the Silesian Geophysical Station in Racibórz), and Biuletyn Obserwatorium Sejsmologicznego w Krakowie (Bulletin of the Seismological Observatory in Cracow).

The first two titles were previously issued by the State Geological Institute. The publication of all three bulletins, edited by Prof. Tadeusz Olczak, was terminated on the experimental data from the year 1958. Data since 1959 have been included to the series Materiaty i Prace series discussed later on.

\subsection{Prace Obserwatorium Geofizycznego im St. Kalinowskiego w Świdrze (1959-1976)}

It contained the magnetic recording through the years 1953-1967 and atmospheric electricity recordings through the years 1957-1965, as well as related papers. A total of 21 magnetic yearbooks and 9 atmospheric electricity yearbooks, and a Jubilee Book to commemorate the 50-th anniversary of the Observatory (it was founded in 1910) were published. The editors were: Prof. Tadeusz Olczak and then Dr. Zdzisław Małkowski.
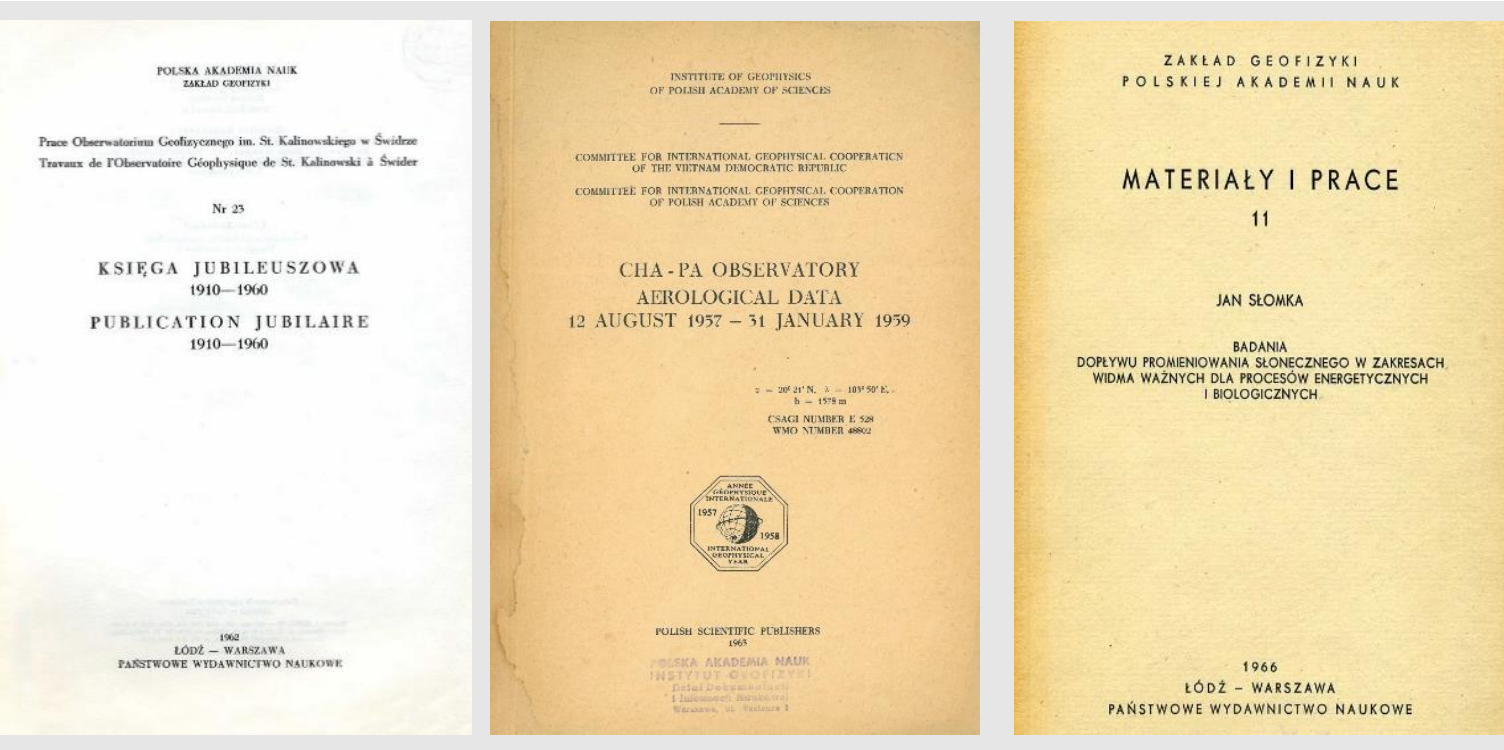

Fig. 1. Some covers of the early publications. 


\subsection{Materiały i Prace Zakladu Geofizyki PAN (1963-1976)}

The separate titles enumerated above were included into the newly created broad series Materiaty i Prace Zakładu Geofizyki PAN, covering, along with observatory results, also original scientific papers, selected habilitation treatises, selected doctoral theses, conference materials, and the like. In 1973 the series evolved to Publications of the Institute of Geophysics, Polish Academy of Sciences, discussed later on.

\section{ACTA GEOPHYSICA POLONICA / ACTA GEOPHYSICA}

\subsection{History}

The first issue of Acta Geophysica Polonica (AGP) bears the date of March 25, 1953. The Editorial included the following declaration:, ,[...] we expect Polish geophysicists to acknowledge with pleasure the appearance of Acta Geophysica Polonica - a forum for presenting the results of their research. We hope, it will contribute to the development of geophysics in Poland and promote the exchange of achievements of our scientists with those in other coun-

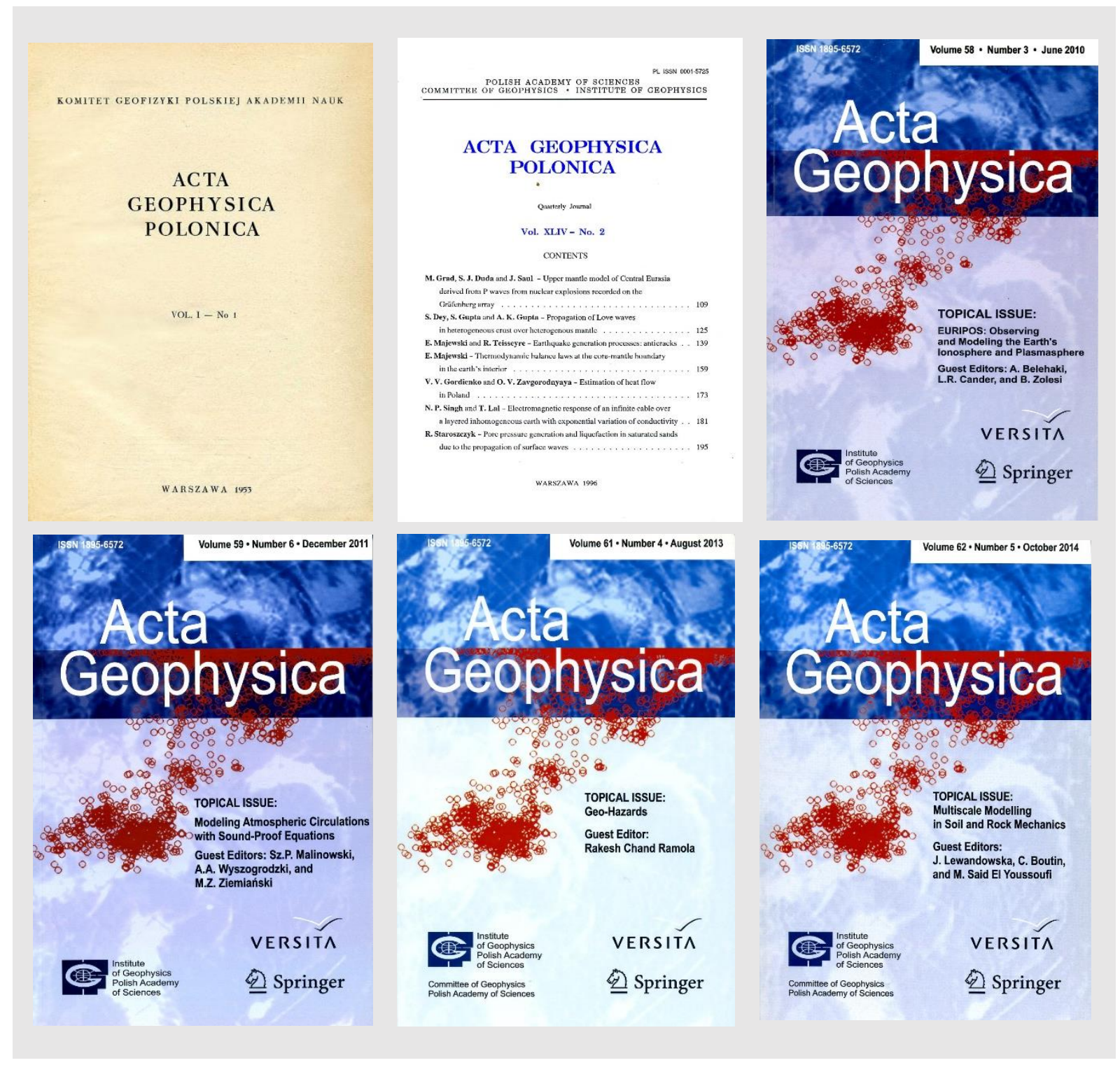

Fig. 2. Exemplary covers of Acta Geophysica Polonica / Acta Geophysica, including the first issue and some topical issues. Now the journal is published online, we resigned from the printed version. 
tries." And this line has been kept until the present times. Under a slightly modified title of Acta Geophysica $(A G)$, it is the leading geophysical journal in Poland and highly recognized abroad (some covers are reproduced in Fig. 2).

Looking over the back issues we may observe some impact of politics. The most vivid example is already in the first issue, whose publication coincided with the death of Joseph Stalin, hence it began with his photo and a servile note, as in most Polish journals. The evolution of the language of articles is another example. The Russian-language abstracts were gradually disappearing, while English was becoming dominant, and since 1982 the only language for publication. Polish abstracts to English-language papers were kept until 1991. The number of authors from abroad has been growing.

These changes were in line with political transformations in our country and elsewhere. The recognition of scientific publications on the world scale was becoming more and more important. The role of Acta Geophysica Polonica in international scientific communication 19962003 was described by Racki (2004).

Since 2007 Acta Geophysica has been covered by the Science Citation Index Expanded (Thomson Scientific, Philadelphia) and Current Contents/Physical, Chemical and Earth Sciences. The most popular measure of journal's ranking, the Impact Factor trend, is demonstrated in Fig. 3.

$3.000-100 \%$

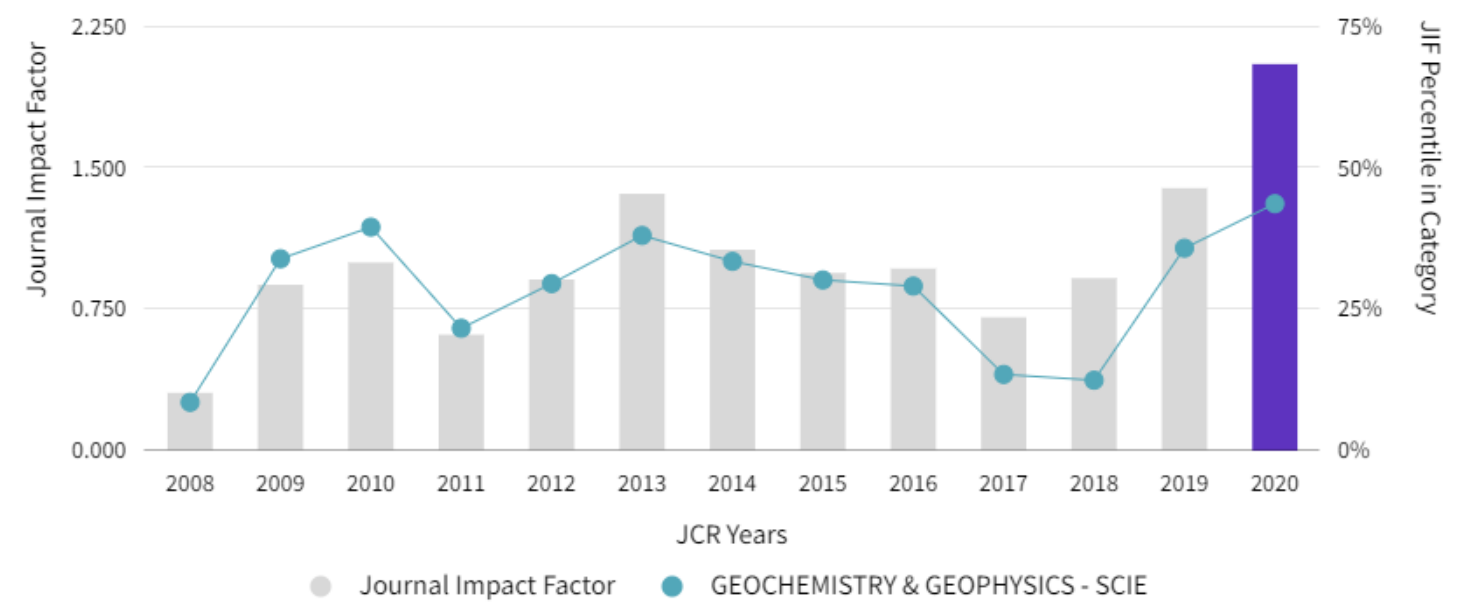

Fig. 3. Impact Factor trend of Acta Geophysica (Web of Knowledge).

Acta Geophysica is mainly focused on original scientific contributions. Alongside, there have also been many articles commemorating the achievements of Polish scientists associated with the journal or other prominent geophysicists (often as a post-mortem tribute). Already in volume 2 there is an article devoted to the 50-year anniversary of scientific work of A.B. Dobrowolski, a world-famous Antarctic explorer. In the next volume, there is an obituary of Prof. Tadeusz Banachiewicz - a famous mathematician, emphasizing his contribution to astronomy, geodesy, and geophysics. Of course, the death (in 1954) of Prof. Edward Stenz, the Editor-inChief, was followed by an article devoted to his life, scientific output, including a broad bibliography. Also the 100 anniversary of his birth has been commemorated. The tribute was also paid to Prof. M.P. Rudzki on the occasion of the 100 anniversary of birth.

Other prominent persons associated with the journal included two physicists, Professors Stefan Pieńkowski and Czesław Białobrzeski, Professors Edward W. Janczewski from the Academy of Mines in Cracow, Teodor Kopcewicz from the University of Warsaw, Stefan 
Manczarski, former Director of our Institute, and Stanisław Maloszewski. After the death of Prof. Henryk B. Arctowski, the most eminent Polish explorer of Polar regions and well-known meteorologist and climatologist, a special issue to honor him was published.

In more recent times, the journal lost two persons of great merits: the former Editor-in-Chief Prof. Sławomir Jerzy Gibowicz (1933-2011), well-known seismologist, who established fundamentals of mining geophysics, and Prof. Kacper Mieczyslaw Rafal Rybicki (1940-2008), Director of the Institute of Geophysics PAS, highly esteemed geophysicist, planetologist, and astrophysicist.

Last but not least, it is to be emphasized with satisfaction that Adam M. Dziewoński, (1936-2016), the 1998 Crafoord Prize winner, Professor of Harvard University, Cambridge, MA, USA, who began his scientific career in Poland, published his first three papers in Acta Geophysica Polonica, and was a member of the AG Advisory Board for many years. The Crafoord Prize winners are treated as Noblists.

\subsection{Publishers and editors}

From the very beginning, $A G P$ was co-published by the Institute of Geophysics PAS and the Committee of Geophysics PAS. Until 1991, the editing and printing were carried out by the Polish Scientific Publishers PWN. Afterwards, the camera-ready copies were prepared at the Editorial Office of the Institute of Geophysics and printed by the Editorial Team of the Space Research Center, and then the private enterprise Remigraf.

In 2005 the journal acquired a new co-publisher, Central European Sciences Journals (then re-named into Versita, and in 2014 incorporated into De Gruyter). Since 2006, Acta Geophysica has become one of Springer-Verlag journals accessible through Springerlink at http://www.springer.com/journal/11600. The Institute of Geophysics is the owner of the journal, responsible for all editorial work. The typesetting is now made by Springer. These changes strongly enhanced the availability of $A G$ around the world. Also the editorial and scientific standard of publications has grown. The review, performed by at least two referees, is now quite rigorous and many papers are rejected.

The first Editor-in-Chief of $A G P$, as we already mentioned, was Prof. Edward Stenz, holding this position from 1953 to his death in 1956. He was superseded by Prof. Tadeusz Olczak (1956-1982) and then Prof. Slawomir J. Gibowicz (1982-1994). The next Editor-in-Chief was Prof. Roman Teisseyre (1995-2005), strongly associated with the journal from the very beginning, probably one of the most frequent authors in the early years of the journal. He was followed by Prof. Stanisław Lasocki (2006-2010), who expanded the Editorial and Advisory Board, incorporated Associate Editors responsible for papers in particular areas of geophysics, and included a Special Section on Triggered and Induced Seismicity. The photo of the Editorial Team in 2007 is in Fig. 4.

Since 2010 up to 2016, the Editor-in Chief has been Prof. Jarosław Napiórkowski. Under his guidance, the hitherto quarterly journal has expanded into a bi-monthly one. Later on, the position has been taken by Prof. Eleftheria E. Papadimitriou from the Aristotle University of Thessaloniki.

The Advisory Board includes prominent scientists from the leading universities, mostly in the United States and Europe, notably from Greece. The current list of Advisory Board members and Associate Editors is available at http://agp.igf.edu.pl/.

Over the years, eight persons performed the duty of Managing Editor, including Maria Wernik in the years 1976-2009, Iwona Brzuska in 2010-2012, and Dr. Zbigniew Wiśniewski since then. In 2021, a second Managing Editor, Roksana Chmielowska, joined the staff. 


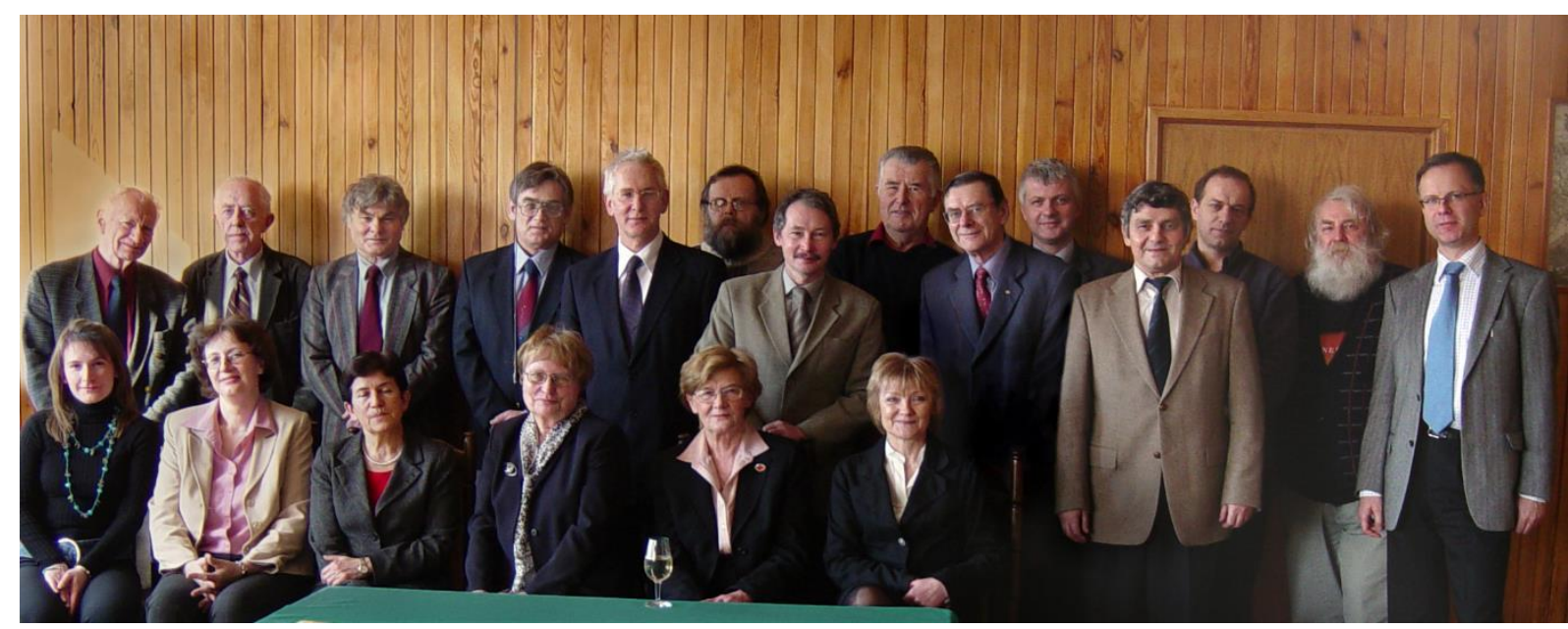

Fig. 4. Acta Geophysica Editorial Team on 23 January 2007. Standing: Roman Teisseyre, Sławomir Gibowicz, Kacper Rybicki, Zbigniew Sorbjan, Stanisław Lasocki, Szymon Malinowski, Zbigniew Czechowski, Janusz Borkowski, Andrzej Wernik, Andrzej Leśniak, Jarosław Napiórkowski, Wojciech Dębski, Marek Grad, Paweł Rowiński. Sitting: Iwona Brzuska, Marzena Czarnecka, Jadwiga Jarzyna, Anna Dziembowska, Maria Wernik, Iwona Stanisławska (Photo by Marek Górski).

\subsection{Special/Topical Issues}

Special or Topical Issues have been published throughout the whole 70-year history of the journal, starting with the issue devoted to the International Geophysical Year 1957/58. The present policy is to increase the number of issues to be focused on specific, hot topics of utmost interest.

\section{PUBLICATIONS OF THE INSTITUTE OF GEOPHYSICS, POLISH ACADEMY OF SCIENCES}

It is a continuation of Materiaty i Prace Zakładu Geofizyki PAN, but under English-language title; the continuity of numbering was kept.

Publications of the Institute of Geophysics has become the basic editorial series, serving as a main platform for publishing the observatory results, conference proceedings, some doctoral theses and habilitation treatises. The proceedings were related to important international conferences, like General Assembly of the European Seismological Commission in 1976, Europrobe Symposium in 1991, IAGA Workshop in 2006, consecutive Polish-Czech-Slovakian Mining Geophysics Conferences, some meetings of the International School of Hydraulics, and many other. The most important issues were labeled with a subtitle "Monographic Volume", and were in fact monographs. Some covers to illustrate the evolution of the journal are shown in Fig. 5.

At present, it covers the following subject series:
A - Physics of the Earth's Interior,
B - Seismology,
$\mathrm{C}$ - Geomagnetism,
D - Physics of the Atmosphere,
E - Hydrology (formerly Water Resources),
P - Polar Research (since 2017),
M - Miscellanea.

In 2017, after 55 years of being the Editor-in-Chief, Prof. Roman Teisseyre resigned from this position, but agreed to support us further as the Honorary Editor. We are very grateful to this Outstanding Scientist for creating and managing this journal for so many years. The position of the Editor in Chief has been taken over by Dr. Marek Kubicki. 
Also in 2017, a subtitle "Geophysical Data Bases, Processing and Instrumentation" was added to underline the fact that the publication became mainly focused on experimental results from the Institute of Geophysics PAS, but contributions from other scientific institutions are also highly welcome.

Our objective is to publish innovative research in various, currently vital aspects of geophysical phenomena and climate change. The materials are presented as individual publications or collections of papers (contributed volumes or special issues). Some papers are published "online first", being later attributed to a specific issue. Most issues have only the electronic versions.

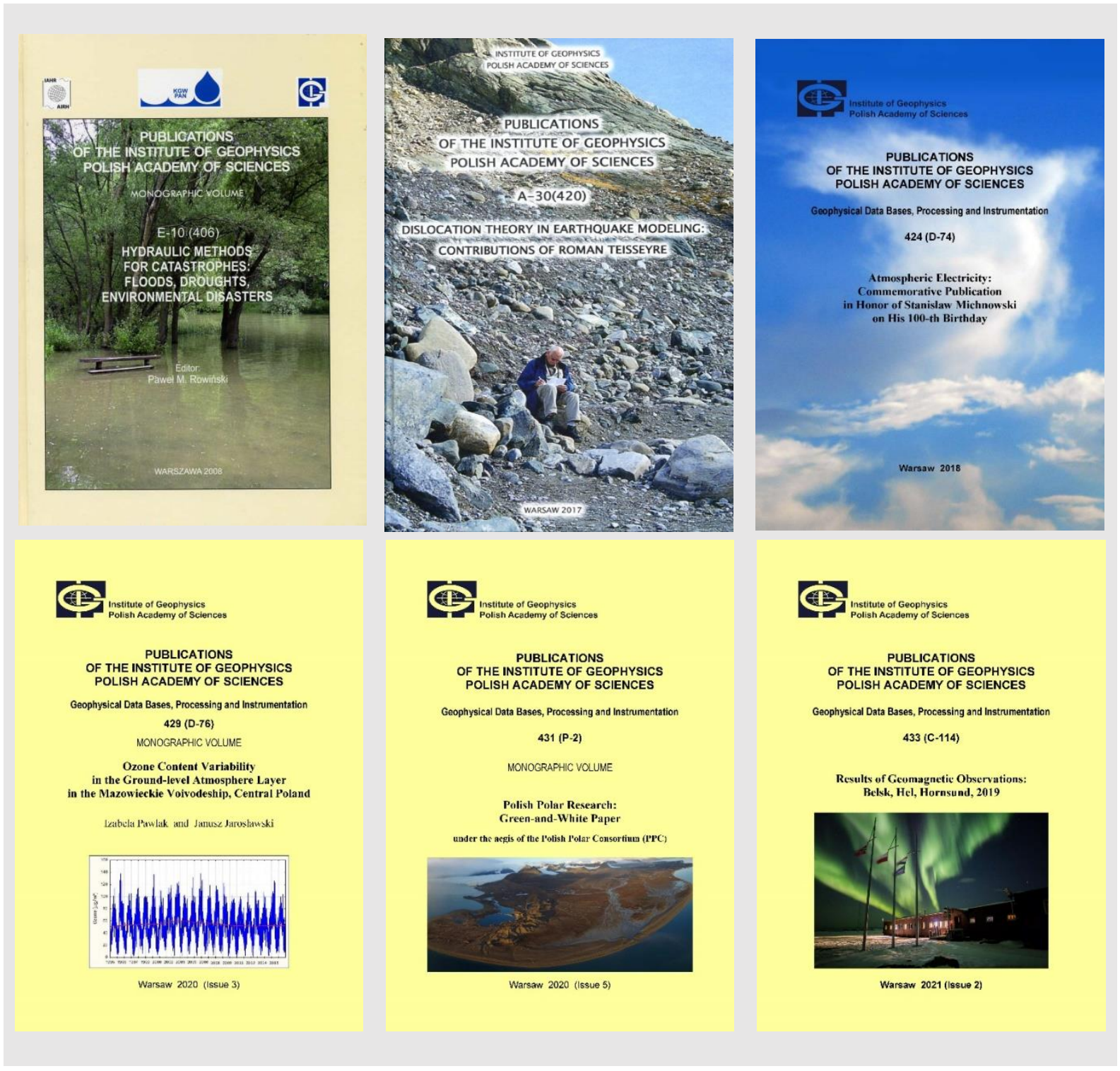

Fig. 5. Covers of Publications of the Institute of Geophysics, Polish Academy of Sciences.

\section{GEOPLANET: EARTH AND PLANETARY SCIENCES SERIES}

The idea to create a new editorial series was born once a new interdisciplinary center, gathering four institutes of the Polish Academy of Sciences, came into being. The GeoPlanet Center was established in March 2009. At present, it is composed of the following five institutes affiliated 
with the Polish Academy of Sciences: Institute of Geophysics, Space Research Centre, Institute of Oceanology, Institute of Geological Sciences, and Nicolaus Copernicus Astronomical Center.

The publications encompass topical monographs and selected conference proceedings, authored or edited by leading experts of international repute as well as by promising young scientists. It is issued in both printed and online versions.

The Editor-in-Chief is Prof. Pawel Rowiński. Associate Editors: Professors Marek Banaszkiewicz (Space Sciences), Janusz Pempkowiak (Oceanology), Marek Lewandowski (Geology, Polar Sciences), and Marek Sarna (Astronomy). The Advisory Board is composed of scientists from many countries. The author of this article, Anna Dziembowska, is the Managing and Language Editor.

The publications are produced in close cooperation between the GeoPlanet Series Editors and Springer-Verlag. The issues are available through the Springerlink and distributed by Springer. From Springer's side, the publication is managed by Ms. Annett Buettner. More information is available at the addresses: http://www.igf.edu.pl/pl/publikacje/geoplanet_series and http://www.springer.com/series/8821.

The interest in publishing books within the GeoPlanet Series is large. We are currently publishing 2-3 books per year. Covers of six recent issues are reproduced in Fig. 6.
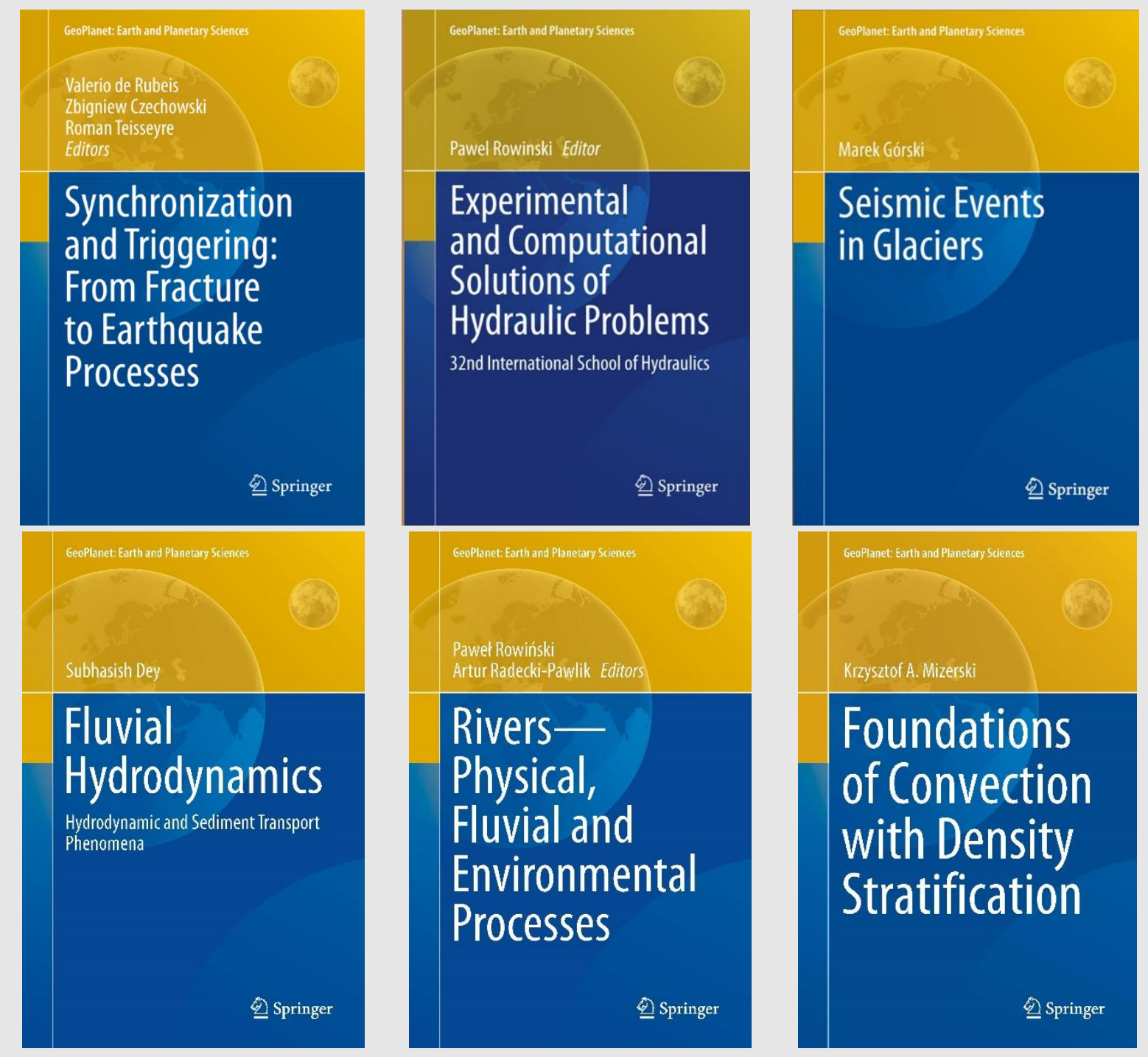

Fig. 6. Covers of some issues of GeoPlanet books published in the years 2010-2021. 


\section{SOME OUTSTANDING MONOGRAPHS WRITTEN BY MEMBERS OF THE INSTITUTE OF GEOPHYSICS STAFF}

Members of the Institute's staff have produced numerous valuable, often pioneering monographs in various branches of geophysics, as well as academic handbooks and popular science books, which were published by renowned publishers in Poland and elsewhere. Initially, they were issued by the Polish Scientific Publishers PWN, then Elsevier, Springer, and other. The books were initially meant for Polish readers, being gradually addressed to international audience, so the English language began to prevail. Some covers are reproduced in Fig. 7.

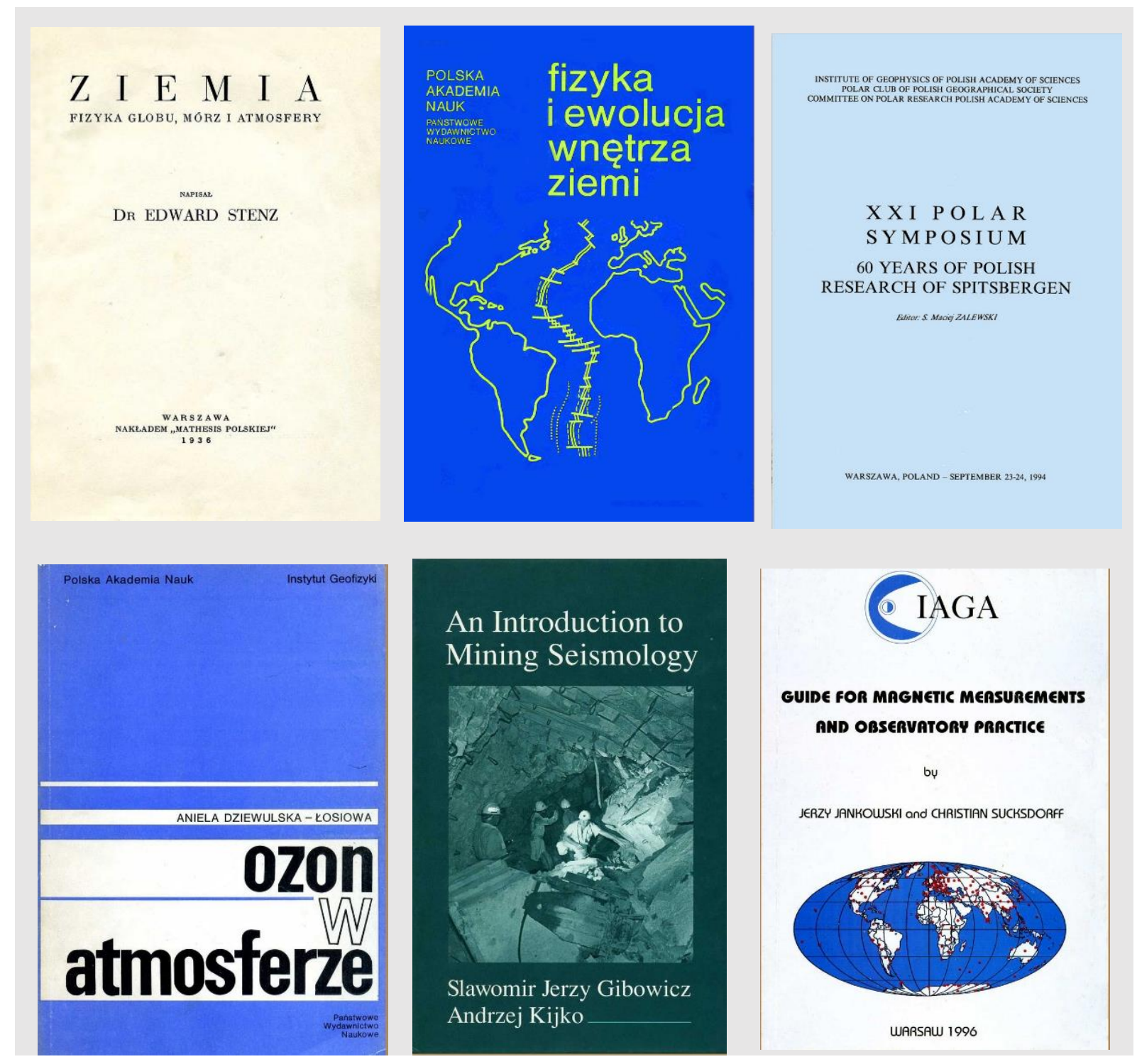

Fig. 7. Some early monographs written by members of the Institute of Geophysics.

Looking over the Institute's output in terms of monographs, the role of Prof. Roman Teisseyre is crucial. It was due to his initiative, patience and diligence that the widely recognized 6-volume series under the common title Physics and Evolution of the Earth's Interior was completed (Fig. 8). It was preceded by a two-volume monograph in Polish, and followed by next monographs, including two ones in the GeoPlanet Series discussed separately. At the wide theoretical and experimental background, the books present various stages of developments in earthquake physics. 


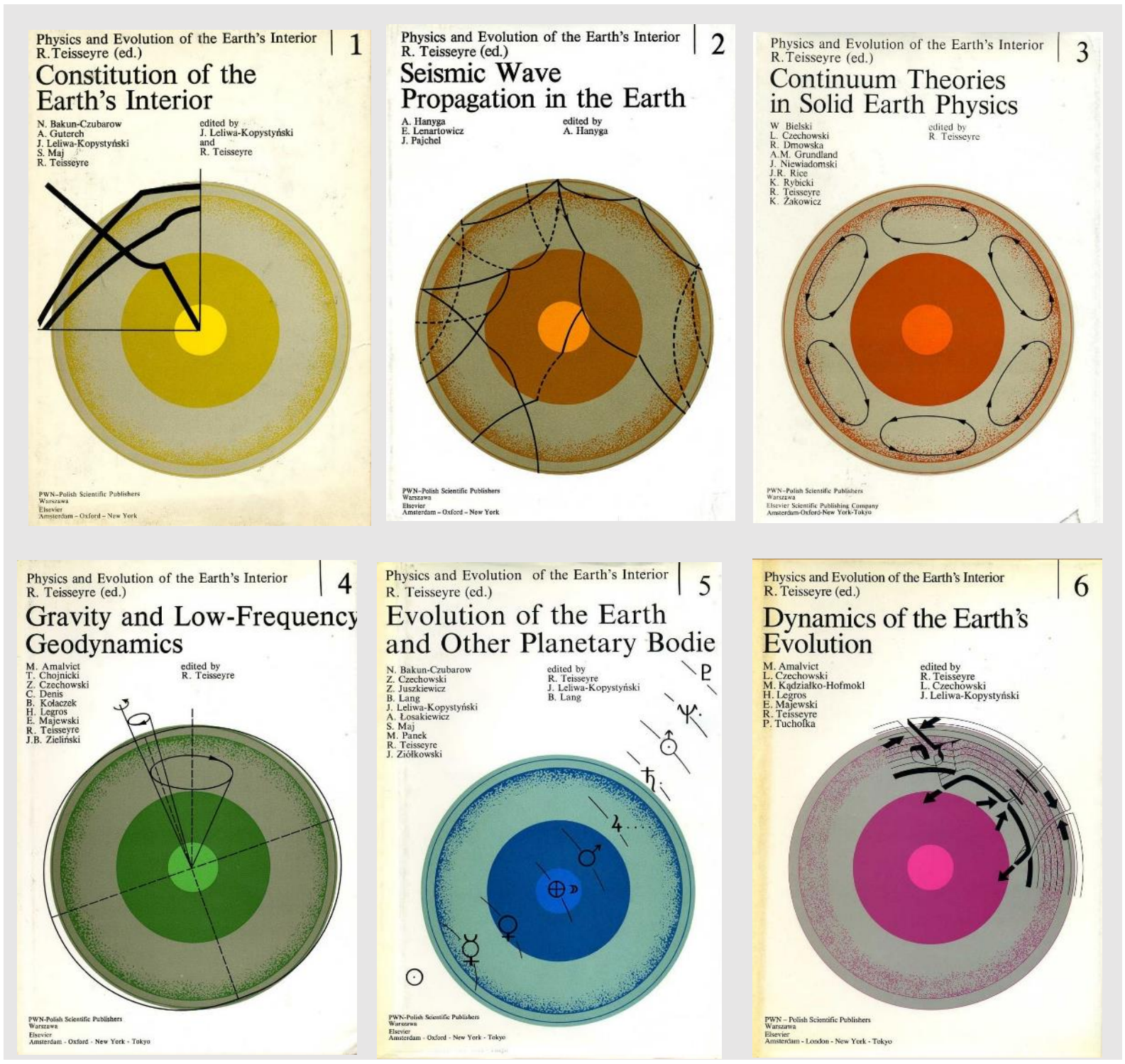

Fig. 8. Six volumes of the monograph Physics and Evolution of the Earth's Interior edited by Prof. Roman Teisseyre.

\section{POPULAR SCIENCE}

The continuing efforts of the Institute of Geophysics to share the knowledge on a broad scope of geosciences (and other natural sciences) with school children and a general audience have led to numerous actions, the most prominent being two large innovative projects: EDUSCIENCE (Effective Way of Teaching Natural Sciences at Schools) and EDUARCTIC.Pl (educational program attracting young people to polar research), as illustrated below (Fig. 9).

\section{BIBLIOGRAPHIC DATABASES}

Bibliographic databases relating to the Institute of Geophysics have been regularly published in printed form until 1993 in Publications of the Institute of Geophysics (Vols. 73, 138, 232, 266), and since 1994 to 2008 on the Internet at http://www.igf.edu.pl/en/publikacje/ bibliographical_database. 

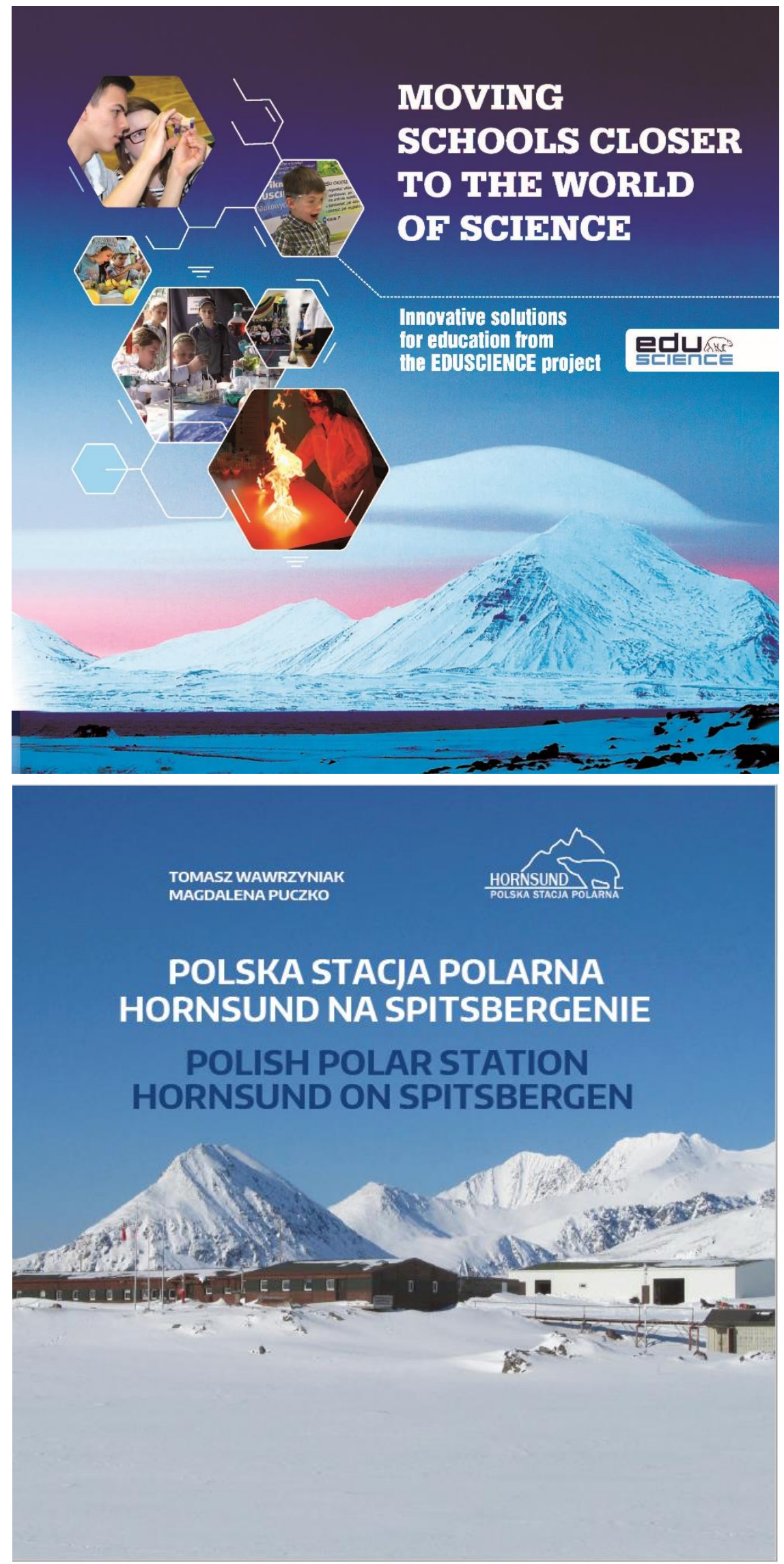

Fig. 9. A book describing and promoting the EDUSCIENCE project and an album on the Polish Polar Station in Spitsbergen. 
The professional bibliographies were prepared by the experienced documentalist Dr. Kazimiera Warzechowa, and then, after her death, by Zofia Okrasińska. Worth mentioning is also a two-volume of bibliography of Polish research in Spitsbergen (Zalewski 2000, Giżejewski 2010).

Acknowledgements. I made use of historical articles and obituaries written by our late colleagues, Dr. Kazimiera Warzechowa, Dr. Bożenna Gadomska, Prof. Sławomir Maj, as well as Prof. Jerzy Kowalczuk from the AGH University of Science and Technology in Kraków (to name just a few publications: Ołpińska-Warzechowa 1974, 1995; Gadomska 2004; Maj 1996; Kowalczuk 2001). It is due to their work that many achievements and facts of importance are commemorated.

\section{References}

Dziembowska, A., and M. Wernik (2014), Sixty years of publishing with the Institute of Geophysics. In: R. Bialik, M. Majdański, and M. Moskalik (eds.), Achievements, History and Challenges in Geophysics, Geoplanet: Earth and Planetary Sciences, Springer, Cham, 197-210, DOI: 10.1007/978-3-319-07599-0_11.

Gadomska, B. (2004), Kronika Instytutu Geofizyki PAN, 1952-2002 [Institute of Geophysics, Polish Academy of Sciences - Chronicle, 1952-2002], Publs. Inst. Geoph. PAS M-26 (348), 23-59.

Giżejewski, J. (ed.) (2010), Bibliography of Polish Research in Spitsbergen Archipelago, Part II, 19972006, Publs. Inst. Geoph. PAS M-31 (407), 149 pp.

Kowalczuk, J. (2001), 100-lecie Geofizyki Polskiej 1895-1995, Kalendarium [100 Years of Polish Geophysics, 1895-1995, Calendarium], 2nd ed., Arbor, Kraków, 234 pp.

Maj, S. (1996), Quarterly journal „Acta Geophysica Polonica”, Prz. Geofiz. 41, 1-2.

Ołpińska-Warzechowa, K. (1974), Publications of the Institute of Geophysics, Polish Academy of Sciences, Mat. i Prace Inst. Geofiz. 73, 195-202.

Ołpińska-Warzechowa, K. (1995), Geofizyka [Geophysics]. In: Z. Mikulski (ed.), Historia Nauki Polskiej, Wiek XX, Nauki o Ziemi, IHN PAN, Warszawa, 37-82 (in Polish).

Racki, G. (2004), Role of Acta Geophysica Polonica in international scientific communication 19962003, Publs. Inst. Geoph. PAS M-26 (348), 71-92 (in Polish with English abstract).

Zalewski, S.M. (ed.) (2000), Bibliography of Polish Research in Spitsbergen Archipelago. Part I: 19301996, Publs. Inst. Geoph. PAS M-23 (314), 194 pp. 